\title{
Synthesis of Some of Fluorinated Benzimidazole Nucleosides
}

\author{
Laila M. Break \\ Correspondence: Laila M. Break, Taif University, Al-Haweiah, P.O.Box 888 Zip Code 21974. Taif, Saudi Arabia. Tel: \\ 966-555043306. E-mail: lailabreak@hotmail.com
}

Received: December 31, 2015 Accepted: January 21, 2016 Online Published: January 26, 2016

doi:10.5539/ijc.v8n1p188 URL: http://dx.doi.org/10.5539/ijc.v8n1p188

\begin{abstract}
Fluorinated nucleosides very important in increased biological and chemical stability of organ fluorine compounds. Synthesis of two 5-(Trifluoromethyl)- $1 H$-benzimidazole derivatives (3) and (4).

Ribosylation of each compound (3) and (4) with 1-O-acetyl-2,3,5-tri- $O$-benzoyl- $\beta$-D-ribofuranose (6) afforded mixture $b$ - and $a$ - anomeric of the benzoylated nucleoside derivatives (8), (9) and $b$ - anomeric (12), respectively. Debenzoylation of the protected nucleosides by reaction with sodium metal in dry methanol yielded the corresponding free $\mathrm{N}$-nucleosides (10), (11) and (13) respectively. The new synthesized compounds were characterized using the well-known spectroscopic tools (IR, ${ }^{1} \mathrm{HNMR},{ }^{13} \mathrm{CNMR}$ and mass spectroscopy).
\end{abstract}

Keywords: reduction, Benzimidazole, fluorinated benzimidazole, Trifluoromethyl, Nucleosides, 1-O-Acetyl-2,3,5-trihydroxy--D-ribofuranose, 5-trifluoromethyl-1H, 3H-2-thiono benzimidazole

\section{Introduction}

Benzimidazoles are important of heterocyclic compounds that have been used_biological actives such as anesthetic, antipyretic, antiulcer, antihypertensive antifungal, antihistaminic, anticancer, antitumor ant proliferative activitie, antimicrobial including anti-HIV, antioxidant, cysticidal activities inhibitors of Plasmodium and cholinesterase inhibitor activities. (M. Ross Grimmett et al, 1996; Violeta R, 2010; Samuthirarajan, 2014; M. Rashid et al, 2015; Geeta Yadav and Swastika Gangly, 2015; Alpan AS et al, 2013)

Fluorinated nucleoside analogues are very important biologically. More active against known drug 5-fluorouracil (5-FU) in some tumor cell lines anticancer activity against leukemia, colon, melanoma, renal, breast cancer cell lines. and inhibiting the growth of myeloid cell.(A. Khalafi-Nezhad et al, 2002)

Fluorinated nucleosides have been used as inhibitors of various enzymes, inhibitors of HIV-1, rheumatoid arthritis, hepatitis C virus (HCV), (Sharma A et al 2013; Hanna Wo and jtowicz-Rajchel, 2012) against hepatitis-B virus (HBV), Varicella zoster virus (VZV), cytomegalovirus (CMV), and Epstein-Barr virus (EBV). (Peng Liu et al, 2008)

In this review, important synthetic for fluorinated benzimidazole nucleosides.

\section{Material and Methods}

IR spectra were recorded for $\mathrm{KBr}$ discs on Fourier Transform infrared and Pie Unicom SP 300 Infrared Spectrophotometers at Taif University. ${ }^{1} \mathrm{H}$ NMR spectra were obtained on a Varian (850 MHz) EM 390 USA instrument at King Abdel-Aziz University by using TMS as internal reference. ${ }^{13} \mathrm{C}$ NMR spectra were recorded on a JNM-LA spectrometer $(850 \mathrm{MHz})$ at King Abdel-Aziz University, Saudi Arabia. Mass spectra were recorded on a JEOL-JMS-AX500 at King Abdel-Aziz University, Saudi Arabia. Elemental analyses were obtained on an Elementary Vario EL 1150C analyzer. Purity of the compounds was checked by thin layer chromatography (TLC). Thin layer chromatography (TLC) was performed on silica gel sheets F1550 LS 254 of Schleicher \& Schull and column chromatography on Merck silica gel 60 (particle size 0.063-0.20. Melting points were measured on Gallenkamp melting point apparatus (UK) and are uncorrected. The starting materials 4-Amino-3-nitrobenzotrifluoride (1) was prepared Pubchem CID: 67865.

\section{Experimental}

\section{3,4-Diaminobenzotrifluoride (2)}

Reduction of nitro group of 4-Amino-3-nitrobenzotrifluoride (1) by Raney Nickle and hydrazine to obtained 3, 4-Diaminobenzotrifluoride (2), yield (87\%), m.p. $56{ }^{\circ} \mathrm{C}$ brown. (Laila Break, 2015) 


\section{5-(Trifluoromethyl)-1H-1,3-benzoimidazole (3)}

Heating (3g, $0.0161 \mathrm{~mole}$ ) of (2) with $20 \mathrm{ml}$ formic acid for $24 \mathrm{~h}$. The axcess of formic acid was removed by distillation, and neutralized with $0.5 \mathrm{M} \mathrm{NaOH}$, the product was purified by flash column chromatography silica gel $100 \mathrm{~g}$, (chloroform /ethyl acetate 90: 10). Crystaylation in EtOH. Yield 2.85g (90\%), m.p. $<300{ }^{\circ} \mathrm{C}$ brown; IR $(\mathrm{KBr}) v \mathrm{~cm}^{-1}$ : $3400(\mathrm{NH}) ; 1630(\mathrm{C}=\mathrm{N}) .{ }^{1} \mathrm{HNMR}(600 \mathrm{MHz}) ;\left(\mathrm{CD}_{3} \mathrm{OD}\right): \delta 8.31(\mathrm{~s}, 1 \mathrm{H}, \mathrm{H}-2) ; 7.90(\mathrm{~s}, 1 \mathrm{H}, \mathrm{H}-4) ; 7.70(\mathrm{~d}, 1 \mathrm{H}, J=8.4 \mathrm{~Hz}$, $\mathrm{H}-6) ; 7.47(\mathrm{~d}, 1 \mathrm{H}, \mathrm{J}=8.4 \mathrm{~Hz}, \mathrm{H}-7), 5.02(\mathrm{~s}, 1 \mathrm{H}, \mathrm{NH}) .{ }^{13} \mathrm{CNMR}(600 \mathrm{MHz}) \mathrm{CD}_{3} \mathrm{OD}: \delta 145.17,129.01,127.22,125.92$, 123.63, 120.57, 116.26, 114.52., Anal. Calcd. for $\mathrm{C}_{8} \mathrm{H}_{5} \mathrm{~F}_{3} \mathrm{~N}_{2}$; M.wt: 186.13; C,51.62; H, 2.71; F,30.62; N, 15.05; (\%); Found: C, 47.13; H, 3.01; F, 30.04; N,15.10 (\%).

\section{5-(Trifluoromethyl)-2-thiono-1H-1,3-benzoimidazole $(4)$}

Compound (2) ( $3 \mathrm{~g}, 0.0161 \mathrm{~mol}$ ) was dissolved in $\mathrm{EtOH}$ and $0.5 \mathrm{~g}$ of $\mathrm{NaOH}$. (3ml) of $\mathrm{CS}_{2}$ was added drop to drop. The mixture was stirred at room temperature for $1 / 2 \mathrm{~h}$, it changed color from brown to yellow and H2S gas generated. The mixture was reflexed for $4 \mathrm{~h}$ then the solvent was evaporated. Acetic acid was added to the residue, the brown precipate was formed. Purification of the residue was accomplished via silic gel column chromatography eluting with (chloroform /ethyl acetate 90: 10). Crystaylation in EtOH. Yield $2.98 \mathrm{~g}(80 \%)$, m.p. $248{ }^{\circ} \mathrm{C}$ dark brown. $\mathrm{IR}(\mathrm{KBr}) v \mathrm{~cm}^{-1}$ : $3400(\mathrm{NH}) ; 1630(\mathrm{C}=\mathrm{N}) 1560(\mathrm{C}=\mathrm{S}) ;{ }^{1} \mathrm{HNMR}(600 \mathrm{MHz}) ;\left(\mathrm{CDCl}_{3}\right):{ }^{1} \mathrm{HNMR}(600 \mathrm{MHz}): \delta 7.36(\mathrm{~s}, 1 \mathrm{H}, \mathrm{H}-4) ; 7.33(\mathrm{~d}$, $1 \mathrm{H}, \mathrm{H}-6) ; 6.88(\mathrm{~d}, 1 \mathrm{H}, \mathrm{H}-7) ; 5.57(\mathrm{~s}, 1 \mathrm{H}, \mathrm{NH}) ; 5.30(\mathrm{~s}, 1 \mathrm{H}, \mathrm{NH}) .{ }^{13} \mathrm{CNMR}(600 \mathrm{MHz})$ DMSO: $\delta$ 186.48, 175.46, 140.18, 127.27, 125.35, 122.74, 121.02, 115.20. Anal. Calcd. for $\mathrm{C}_{8} \mathrm{H}_{5} \mathrm{~F}_{3} \mathrm{~N}_{2} \mathrm{~S} ;$ M.wt: 218.20; C,44.04; H, 2.31; F,26.12; N, 12.84, S, 14.70; (\%); Found: C, 43.89; H, 2.11; F, 26.00; N,12.26; S, 14.29 (\%).

\section{Synthesis of protection nucleoside}

Ribosylation each of 5-trifluoromethyl Benzimidazoles (3) and 5-trifluoromethyl-1H,3H-2-thiono benzoimidazole (4).

\section{General Procedure.}

A mixture of each 5-(trifluoromethyl)- $1 H$-1,3- Benzimidazoles (3) and 5-trifluoromethyl-1H,3H-2-thiono Benzimidazoles (4) $(0.02 \mathrm{~mol})$ and hexamethyldisilazane $(20 \mathrm{ml})$ were heated under reflux for $24 \mathrm{~h}$ with a catalytic amount of ammonium sulfate $(0.01 \mathrm{~g})$. After that, the clear solution was cooled and evaporated till dryness to give the silyated derivatives (5) and (6), which directly was dissolved in $20 \mathrm{ml}$ of dry 1,2-dichloroethane and then 1-O-acetyl-2,3,5-tri- $O$-benzoyl-D-ribofuranose $(7)(5.05 \mathrm{~g}, 0.01 \mathrm{~mol})$ was added. The mixture was added drop wise onto a mixture of $(10 \mathrm{ml}$ trimethylsilyl trifluoromethane sulfonate (TMSOTf) in dry 1,2-dichloroethane $(50 \mathrm{ml}))$. Each of mixture was stirred at room temperature for $24 \mathrm{~h}$, and then washed with a saturated solution of aqueous sodium bicarbonate $(3 \times 50 \mathrm{ml})$, washed with water $(3 \times 50 \mathrm{ml})$, and dried over anhydrous sodium sulfate. The solvent was removed in vacuum gave an anomeric mixture of $\beta$ and $\alpha$-1-(2,3,5-tri- $O$-benzoyl- $\beta$-D-ribofuranosyl)5-(trifluoromethyl)-1,3-Benzimidazoles (8) and (9). This mixture has been separted into the two components by on silica gel with Chloroform: Ethyl acetate (9:1) as eluent to afford a white crystal pure $b$-anomeric (8) and $a$-anomeric (9) respecttively. Also of $b$-1-(2,3,5-tri- $O$-benzoyl- $\beta$-D-ribofuranosyl)-5-trifluoromethyl- $1 H, 3 H$-2-thiono benzoimidazole (12) has synthesized . Purification of (12) was accomplished via silic gel column chromatography eluting with (chloroform: Hexane: Acetone 7:3:1).

\section{$\boldsymbol{\beta}$-1-(2,3,5-Tri- $\boldsymbol{O}$-benzoyl- $\boldsymbol{\beta}$-D-ribofuranosyl)-5-(trifluoromethyl)-1,3-benzoimidazole (8)}

Yield (58.60\%), w. 2.80 g, m.p. $118^{\circ} \mathrm{C}$ white; $v\left(\mathrm{~cm}^{-1}\right)(\mathrm{KBr}) 1740(\mathrm{C}=\mathrm{O}), 1670(\mathrm{C}=\mathrm{N}) ;{ }^{1} \mathrm{HNMR}(850 \mathrm{MHz}) ;\left(\mathrm{CDCl}_{3}\right): \delta$ $8.00-7.13(\mathrm{~m}, 18 \mathrm{H}, \mathrm{Ar}-\mathrm{H}) ; 6.66\left(\mathrm{~d}, 1 \mathrm{H}, J=8.5 \mathrm{~Hz}, \mathrm{H}-1^{\prime}\right) ; 5.46$ (m, 1H, H-2'); 5.37 (m 1H, H-3'); 4.60-4.57 (m, 1H, $\left.\mathrm{H}^{\prime} \mathrm{4}^{\prime}\right) ; 4.2-4.30\left(\mathrm{~m}, 1 \mathrm{H}, \mathrm{H}-5^{\prime}\right) .{ }^{13} \mathrm{CNMR}(850 \mathrm{MHz})\left(\mathrm{CDCl}_{3}\right) \delta 166.30,165.46,164.87(3 \mathrm{C}=\mathrm{O}), 157.94,154.56,145.74$, 135.26, 133.81, 133.69, 133.51, 133.24,133.12,131.23,130.08, 129.89, 129.80, 129.77, 129.35, 129.27, 129.06, 128.60, 128.53, 128.46, 128.38, 126.31, 120.56, 120.53, 105.29 (Ar.C's), 86.96, 78.82, 72.56, 64.39, 63.79 (sugar carbons), Anal. Calcd. for $\mathrm{C}_{34} \mathrm{H}_{25} \mathrm{~F}_{3} \mathrm{~N}_{2} \mathrm{O}_{7}$; M.wt: 630.57; C,64.76; H,4.00; F,9.04; N, 4.44; (\%); Found: C, 64.26; H, 3.89; F,9.01; $\mathrm{N}, 4.05(\%)$.

\section{$\boldsymbol{\alpha}$-1-(2,3,5-Tri- $\boldsymbol{O}$-benzoyl- $\boldsymbol{\beta}$-D-ribofuranosyl)-5-trifluoromethyl-1,3-benzoimidazole (9)}

Yield (39.76\%), m.p. $124^{\circ} \mathrm{C}$ white color; ${ }^{1} \mathrm{HNMR}(850 \mathrm{MHz})\left(\mathrm{CDCl}_{3}\right): \delta 8.22-7.26(\mathrm{~m}, 22 \mathrm{H}, \mathrm{Ar}) ; 6.47(\mathrm{~d}, 1 \mathrm{H}, J=6.8$, $\left.\mathrm{H}^{1} \mathbf{1}^{\prime}\right) ; 5.98\left(\mathrm{t}, 1 \mathrm{H}, \mathrm{H}-2^{\prime}\right) ; 5.26$ (t, 1H, H-3'); 4.95 (m, 1H, H-4'); 3.84-3.75(m,1H, H-5'). ${ }^{13} \mathrm{CNMR}(850 \mathrm{MHz}): \delta 169.13$, $165.99,165.37,145.03,133.75,133.58,133.33,130.04,129.95,129.87,129.75,128.57,128.46,84.21,83.39,71.64$, 70.46, 63.91.Anal. Calcd. for $\mathrm{C}_{34} \mathrm{H}_{25} \mathrm{~F}_{3} \mathrm{~N}_{2} \mathrm{O}_{7}$; M.wt: 630.57; C,64.76; H,4.00; F,9.04; N, 4.44; (\%); Found: C, 64.15; H, $3.75 ; \mathrm{F}, 8.91 ; \mathrm{N}, 4.24(\%)$.

\section{$\beta$-1-(2,3,5-Tri- $O$-benzoyl- $\beta$-D-ribofuranosyl)-5-(Trifluoromethyl)-2-thiono-3H-1,3-benzoimidazole (12)}

Yield $(60 \%)$, m.p. $132^{\circ} \mathrm{C}$ white color; IR (KBr) $v \mathrm{~cm}^{-1}: 1760(\mathrm{C}=\mathrm{O}) ; 1630(\mathrm{C}=\mathrm{N}) 1560(\mathrm{C}=\mathrm{S}) ;{ }^{1} \mathrm{HNMR}(850 \mathrm{MHz})$ $\left(\mathrm{CDCl}_{3}\right): \delta 7.90-7.15$ (m, 27H-Ar); $6.32\left(\mathrm{~d}, 1 \mathrm{H}, \mathrm{J}=4.8, \mathrm{H}^{\prime}-1\right) ; 5.81\left(\mathrm{~m}, 1 \mathrm{H}, \mathrm{H}-3\right.$ '); $5.68\left(\mathrm{~d}, J=7.5,1 \mathrm{H}, \mathrm{H}-2^{\prime}\right) ; 4.66(\mathrm{~m}$, 
$\left.1 \mathrm{H}, \mathrm{H}^{\prime} \mathrm{4}^{\prime}\right) ; 4.39$ (m, 1H, H-5'); 1.89 ( $\left.\mathrm{s}, 1 \mathrm{H}, \mathrm{NH}\right) .{ }^{13} \mathrm{CNMR}(850 \mathrm{MHz}): \delta 169.13,165.99,165.37,165.03,145.20,133.70$, 133.60, 133.30, 129.84, 129.75, 129.67, 129.57, 128.52, 128.76, 128.60, 128.55, 128.43, 128.41, 128.35, 98.36, 79.91, 74.94, 71.28, 63.64. Anal. Calcd. for $\mathrm{C}_{34} \mathrm{H}_{25} \mathrm{~F}_{3} \mathrm{~N}_{2} \mathrm{O}_{7} \mathrm{~S}$; M.wt: 662.63; C,61.63; H,3.80; F,8.60; N, 4.23; (\%); Found: C, $61.35 ; \mathrm{H}, 3.52 ; \mathrm{F}, 8.35 ; \mathrm{N}, 4.17$ (\%).

Deprotection of (8), (9) and (12). Synthesis of nucleosides free (10), (11) and (13) respectively.

\section{General Procedure}

A mixture of each protected nucleoside $\beta(\mathbf{8}), \alpha(\mathbf{9})$ and $\beta$ (12) $(0.001 \mathrm{~mol}$ for each), dry absolute methanol (20 ml) and sodium metal $(0.055 \mathrm{~g}, 0.001 \mathrm{~mol})$ was stirred at room temperature for $48 \mathrm{~h}$. The solvent was evaporated under vacuum to give a colorless solid, which was dissolved in hot water and neutralized with acetic acid. The precipitate compound was chromatographic on silica gel with chloroform: ethyl acetate $(9: 1)$ as eluent to afford colorless and white crystals of the corresponding nucleosides (10), (11) and (13) respectively.

\section{$\boldsymbol{\beta}$-1-(2,3,5-Trihydroxy- $\boldsymbol{\beta}$-D-ribofuranosyl)-5-trifluoromethyl-1,3-benzoimidazole (10)}

Yield (85\%), m.p. $288^{\circ} \mathrm{C}$ white color; ${ }^{1} \mathrm{HNMR}(600 \mathrm{MHz})\left(\mathrm{CD}_{3} \mathrm{OD}\right): \delta 8.77$ (s,1H,H-2); 8.62 (s,1H,H-4); 7.84 ( d, $1 \mathrm{H}, J$ $=11.9 \mathrm{~Hz}, \mathrm{H}-6) ; 7.37$ ( dd, 1H, $J=11.05 \mathrm{~Hz}, \mathrm{H}-7) ; 6.06(\mathrm{~d}, 1 \mathrm{H}, J=8.2, \mathrm{H}-1$ '); 4.96 (s, 3H, OH); 4.51 (t, 1H, H-2'); 4.34 ( t, 1H, H-3'); 4.21 ( t, $\left.1 \mathrm{H}, \mathrm{H}-4^{\prime}\right) ; 3.92\left(\mathrm{~m}, 1 \mathrm{H}, \mathrm{H}-5^{\prime}\right) .{ }^{13} \mathrm{CNMR}(600 \mathrm{MHz}) \mathrm{CD}_{3} \mathrm{OD}: \delta 145.64,145.47,139.07,131.27$, 130.25, 128.73, 120.93, 114.21, 91.14, 87.34, 76.24, 71.86, 62.22. Anal. Calcd. for $\mathrm{C}_{13} \mathrm{H}_{13} \mathrm{~F}_{3} \mathrm{~N}_{2} \mathrm{O}_{4}$; M.wt: 318.25; C,49.06; H,4.12; F,17.91; N, 8.80; (\%); Found: C, 48.87; H, 4.07; F,17.84; N,8.05 (\%).

\section{$\boldsymbol{\alpha}$-1-(2,3,5- Trihydroxy- $\boldsymbol{\beta}$-D-ribofuranosyl)-5-trifluoromethyl-1,3-benzoimidazole (11)}

Yield (47\%), m.p. $<300^{\circ} \mathrm{C}$ white color; ${ }^{1} \mathrm{HNMR}(600 \mathrm{MHz})\left(\mathrm{CD}_{3} \mathrm{OD}\right): \delta 8.54$ (s,1H,H-2); $7.92(\mathrm{~d}, 1 \mathrm{H}, \mathrm{H}-4) ; 7.37$ ( t, $1 \mathrm{H}$, , H-6); 7.12 ( t, 1H, H-7); 6.75 (d, 1H, J = 7.65, H-1'); 4.81 (d, 1H, J=4.25 Hz, H-2'); 4.04 ( m, 1H, H-3'); 3.93( m, 1H, H-4'); 3.87 (d, 1H, J=4.25 Hz, H-5'); 3.85 (t, 1H, OH-2'); 3.79 (d,1H, J=9.6Hz, OH-3'); 3.71 (m,1H, OH-5'). ${ }^{13} \mathrm{CNMR}$ (600MHz) $\mathrm{CD}_{3} \mathrm{OD}: \delta 147.03,139.05,131.23,130.21,128.68,119.55,117.54,115.10,83.81,72.14,71.00,69.59$, 64.22Anal. Calcd. for $\mathrm{C}_{13} \mathrm{H}_{13} \mathrm{~F}_{3} \mathrm{~N}_{2} \mathrm{O}_{4}$; M.wt: 318.25; C,49.06; H,4.12; F,17.91; N, 8.80; (\%); Found: C, 48.87; H, 4.07; $\mathrm{F}, 17.84 ; \mathrm{N}, 8.05(\%)$.

\section{$\boldsymbol{\beta}$-1-(2,3,5- Trihydroxy- $\boldsymbol{\beta}$-D-ribofuranosyl)-5-(Trifluoromethyl)-2-thiono-3H-1,3-benzoimidazole (13)}

Yield (87\%), m.p. < $300^{\circ} \mathrm{C} ; \mathrm{CD}_{3} \mathrm{OD}$ : IR (KBr) $v \mathrm{~cm}^{-1}: 3500(\mathrm{OH}) ; 1630(\mathrm{C}=\mathrm{N}) 1560(\mathrm{C}=\mathrm{S}) ;{ }^{1} \mathrm{HNMR}(600 \mathrm{MHz}): \delta 8.44$ (s, 1H, H-4); 7.84 (d, 1H, J= 8.4, H-7); 7.31 (d, 1H, J = 6, H-6); 4.84 (d, 1H, J = 8.2, H-1'); 3.88 (t, 1H, H-2'); 3.79 (d, $\left.1 \mathrm{H}, J=1.2 \mathrm{~Hz} \mathrm{H}-3^{\prime}\right) ; 3.71$ (t, $\left.1 \mathrm{H}, \mathrm{H}-4^{\prime}\right) ; 3.68$ ( t, 1H, H-5'); 3.60-3.56 ( m, 1H, OH-2'); 3.32 ( $\left.\mathrm{s}, 1 \mathrm{H}, \mathrm{OH}-3^{\prime}\right) ; 3.25$ ( dd, $\left.1 \mathrm{H}, \mathrm{OH}-5^{\prime}\right) ; 3.20$ (s,1H, NH) ${ }^{13} \mathrm{CNMR}(600 \mathrm{MHz}): \delta 170.57,145.02,131.32,130.23,130.25,130.04,128.75,128.53$, 82.15, 74.29, 66.02, 63.89, 62.79., Anal. Calcd. for $\mathrm{C}_{13} \mathrm{H}_{13} \mathrm{~F}_{3} \mathrm{~N}_{2} \mathrm{O}_{4} \mathrm{~S}$; M.wt: 350.31; C,44.57; H,3.74; F,16.27; N, 8.00; (\%); Found: C, 44.25; H, 3.37; F,16.04; N,7.85 (\%).

\section{Results and Discussion}

The starting compound, 4-Amino-3-nitrobenzotrifluoride (1) was reduction of nitro group to amine, Using Raney Nickle and hydrazine was prepared, 1,2-Diamino-4-benzotrifluoride (2) as reported in the literature [Laila Break, 2015] (Scheme 1). The chemical structures of nucleoside deriveatives (3)-(10) were established and confirmed on the basis of their elemental analyses and spectral data (IR, ${ }^{1} \mathrm{H}$ and ${ }^{13} \mathrm{C}$ NMR) (see the Experimental section).

Compound (2) was refluxed with formic acid then filtered. The crude compound was purified by column chromatography on silica gel to obtain 5-(Trifluoromethyl)-1,3-benzoimidazole (3). While Compound (2) was reacted with with $\mathrm{CS}_{2}$ in EtOH and $\mathrm{NaOH}$ formed 5-(Trifluoromethyl)-2-thiono- $1 \mathrm{H}, 3 \mathrm{H}$-1,3-benzoimidazole (4)

Ribosylation each of (3) and (4) was achieved by refluxing in hexamethyldisilazane (HMDS) to give the silylated derivatives (5) and (6). The latter was stirred with 1- $O$-acetyl-2,3,5-O-benzoyl- $\beta$-D-ribofuranose (7) in the presence of dry 1,2-dichloroethane as solvent using trimethylsilyl trifluoromethanesulfonate (TMS triflate) as a catalyst for $24 \mathrm{~h}$ (followed by TLC), following the silylation method according to give the corresponding the mixture $\beta$-anomeric (8) and $\alpha$-anomeric (9), and $\beta$-anomeric (12) protected $N$-nucleoside derivatives, respectively, in good yields (Vorbruggen et al, 1981). The mixture was separated by used column chromatography. 

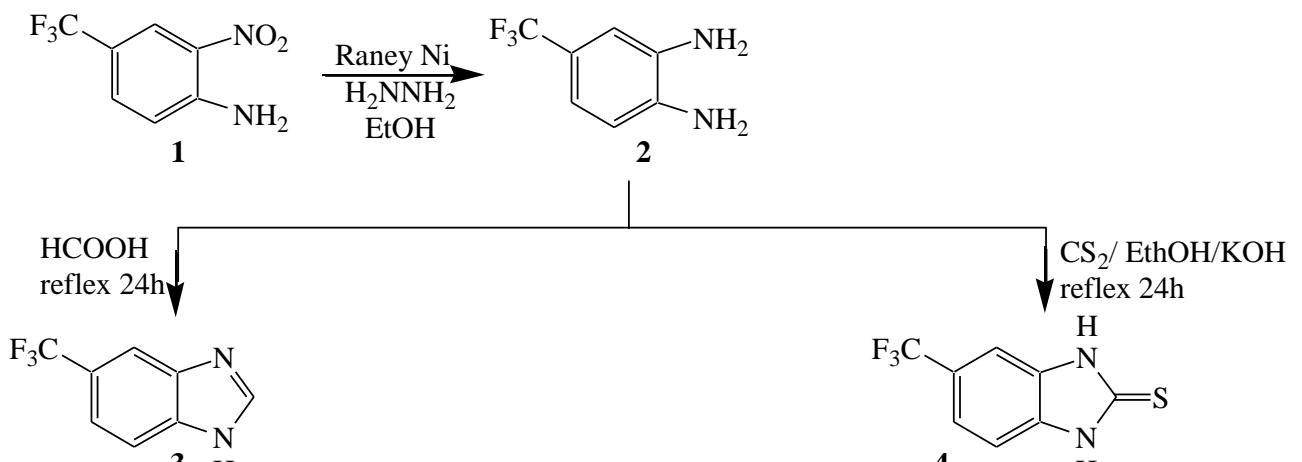<smiles>CSn1c(=S)[nH]c2cc(C(F)(F)F)ccc21</smiles>



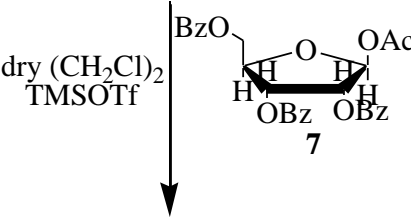<smiles>FC(F)(F)c1ccc2[nH]cnc2c1</smiles>

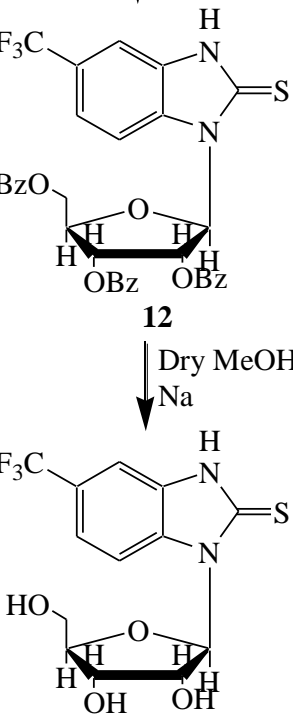

Scheme (1): Synthesis of 5-(Trifluoromethyl)-1,3-benzoimidazole and

5-(Trifluoromethyl)-2-thiono-3H-1,3-benzoimidazole Nucleosides

Debenzoylation of (8), (9) and (12) were performed by using dry absolute methanol and sodium metal following Zemplen et al.'s method (Zemplen et al, 1939) to afford the free nucleosides (10), (11) and (13), respectively. The chemical structures of nucleoside derivatives (2)-(13) were established and confirmed on the basis of their elemental analyses and spectral data (IR, ${ }^{1} \mathrm{H}$ and ${ }^{13} \mathrm{C}$ NMR) (see the Experimental section).

${ }^{1} \mathrm{H}$ NMR spectra of (8), (9) and (13) showed in each case a doublet signals at $\delta 6.66$ for compound (8) and at $\delta 6.47$ for compound 9 and 6.32 for compound 12 assigned to the anomeric proton of the ribose moiety with spin-spin coupling constant $\left(J_{1^{\prime}, 2^{\prime}}\right)$ equal to $8.5 \mathrm{~Hz}$, which confirms the $\beta$-anomeric $(\mathbf{8})$ configuration. While confirms the $\alpha$-anomeric configuration showed spin-spin coupling constant $\left(J_{1^{\prime}, 2^{\prime}}\right)$ equal to $6.8 \mathrm{~Hz}$, which confirms the $a$-anomeric configuration for compound (9), and the spin-spin coupling constant $\left(J_{1^{\prime}, 2^{\prime}}\right)$ equal to $4.8 \mathrm{~Hz}$, which confirms the $\beta$-anomeric (12). (Mosselhi \& Break, 2011; Break et al, 2010; Break et al, 2013, Break et al, 2014; Mosselhi A. N. Mosselhi and Laila M. Break, 2011). 
${ }^{1} \mathrm{H}$ NMR spectra of (10),(11) and (13) showed in each case a doublet signals at $\delta 6.06$ assigned to the anomeric proton of the ribose moiety with spin-spin coupling constant $\left(J_{1,2}\right)$ equal to $8.2 \mathrm{~Hz}$, which confirms the $\beta$-anomeric configuration (10), showed a doublet signals at $\delta 6.75$ the spin-spin coupling constant $\left(J_{1^{\prime}, 2^{\prime}}\right)$ equal to $7.65 \mathrm{~Hz}$, which confirms the $\alpha$-anomeric configuration(11). While $\beta$-anomeric configuration (12) showed a doublet signals at $\delta 4.84$, $\left(J_{1,2}\right)$ equal to $7.65 \mathrm{~Hz}$.

The ${ }^{1} \mathrm{H}$ NMR of (8), (9), (10), (11), (12) and (13) showed the expected base moiety protons in addition to the sugar moiety protons (see the Experimental section).

The ${ }^{13} \mathrm{C}$ NMR of nucleoside products revealed the absence of a thione carbon atom at about $\delta 175$ for product (4),(12) and (13).

The ${ }^{13} \mathrm{C}$ NMR of nucleoside products revealed the signals are due to the three benzoyl carbonyl groups at $\delta 166.30$, 165.46 and 164.87 for compound (8), at $\delta 169.13,165.99$ and 165.37 for compound (9) and showed in addition thione group and the three benzoyl carbonyl groups at $\delta 169.13,165.99,165.37$ and 165.03 , for compound (12). The five signals were assigned to $\mathrm{C}-1^{\prime}, \mathrm{C}-2{ }^{\prime}, \mathrm{C}-3^{\prime}, \mathrm{C}-4{ }^{\prime}$ and $\mathrm{C}-5^{\prime}$ ' of the sugar moiety. The $\mathrm{C}-1$ ' showed at $\delta 86.96,84.21$ and 79.91 for compound (8), (9) and (12), respectively. The ${ }^{13} \mathrm{C}$ NMR of nucleosides free the eight signals were showed for aromatic carbons and five signals were assigned to C-1', C-2', C-3', C-4' and C-5' of the sugar moiety. The C-1' showed at $\delta 91.14,83.81$ and 82.81 for compound $(\mathbf{1 0}),(\mathbf{1 1})$ and $(\mathbf{1 3})$, respectively.

The $\mathrm{CF}_{3}$ group showed at 145.75, 145.03, 145.20, 145.47, 147.03 and 145.02 and of compound (8), (9), (12), (10), (11), and (13) respectively.

The IR spectrum of compounds (8), (9) and (12) showed the stretching vibration frequencies of the benzoyl carbonyl $\mathrm{C}=\mathrm{O}$ groups at $1740 \mathrm{~cm}^{-1}$. IR spectra of compounds (10), (11) and (13) showed absorptions around $3400 \mathrm{~cm}^{-1}$ for $(\mathrm{OH})$. IR spectra each of compounds (4), (12) and (13) showed the stretching vibration frequencies of the thione $\mathrm{C}=\mathrm{S}$ group at $1560 \mathrm{~cm}^{-1}$ ( Jag Mohan, 2004)

\section{Conclusion}

Fluorinated benzimizole nucleosides are importance in many biologically active compounds. Synthesis some of Benzimidazoles Nucleosides and study and characterization. Synthesis of 5-(Trifluoromethyl)-1,3-benzoimidazole (3) and 5-(Trifluoromethyl)-2-thiono-3H-1,3-benzoimidazole (4). Ribosylation of each compound (3) and (4) with 1 - $O$-acetyl-2,3,5-tri- $O$-benzoyl- $\beta$-D-ribofuranose (7) afforded mixture $b$-and $a$-anomeric or $b$-anomeric of the benzoylated nucleoside derivatives $(\mathbf{8}),(\mathbf{9})$ and $(\mathbf{1 2})$, respectively.

Deprotection of the latter by using dry absolute methanol and sodium metal gave new free N-nucleosides (10), (11) and (13), respectively, in moderate yields. Nucleosides obtained have been identified by their spectral analysis.

\section{References}

Alpan, A. S., Parlar, S., Carlino, L., Tarikogullari, A. H., Alptüzün, V., \& Güneş, H. S. (2013). Synthesis, biological activity and molecular modeling studies on $1 \mathrm{H}$-benzimidazole derivatives as acetylcholinesterase inhibitors. Bioorg Med Chem., 21(17), 4928-4937. http://dx.doi.org/10.1016/j.bmc.2013.06.065

Break, L. M., Shmiss, N. A. M. M., \& Mosselhi, A. N. M. (2010). Nucleosides 4: Synthesis of some new S-Nucleoside derivatives of 2-thioxo and 2,4-dithioxo-5,6,7,8-tetrahydrobenzothieno[2,3-d] pyrimi-din-4-(3H)ones. Phosphorus, Sulfur, Silicon \& the Related Elements, 185, 1615. http://dx.doi.org/10.1080/10426500903147159

Geeta, Y., \& Swastika, G. (2015). Structure activity relationship (SAR) study of benzimidazole scaffold for different biological activities": A mini-review. European Journal of Medicinal Chemistry 97, 419-443. http://dx.doi.org/10.1016/j.ejmech.2014.11.053

Grimmett, M. R. (1996). 3.02-Imidazoles. Reference Module in Chemistry, Molecular Sciences and Chemical Engineering. Comprehensive Heterocyclic Chemistry II, Volume 3, 177-220. http://dx.doi.org/10.1016/B978-008096518-5.00060-5

Hanna, W., \& Jtowicz-Rajchel. (2012). Synthesis and applications of fluorinated nucleoside analogues. Journal of Fluorine Chemistry, 143, 11-48. http://dx.doi.org/10.1016/j.jfluchem.2012.06.026

Jag, M. (2004). Organic Spectroscopy: Principles and Applications. Science; 2004 .https://books.google.com.sa/books?isbn=0849339529

Khalafi-Nezhad, A. A., Soltani, M. N., Rad, A., Hakimelahib, G. H., \& Mokhtaria, B. (2002). One step synthesis of imidazole and benzimidazole acycloaromatic nucleoside analogs. Tetrahedron, 58, 10341-10344. http://dx.doi.org/10.1016/S0040-4020(02)01415-1

Laila, M. B. (2015). Synthesis of the Novel 3-Benzotriazole-5-yl-difluoromethyl-5-trifluoromethyl benzotriazole 
Nucleosides. International Journal of Chemistry, 7(2).

Laila, M. B., Mahmoud, A. M., \& Shams, H. A. H. (2014). Synthesis of New Organoselenium Compounds Containing Nucleosides as Antioxidant. Orient. J. Chem., 30(4), 1639-1645. http://dx.doi.org/10.13005/ojc/300423

Laila, M. B., Mosselhi, A. M., \& Nagi, M. E. (2013). Nucleosides 8 [18]: Ribosylation of Fused Quinazolines Synthesis of New [1,2,4]Triazolo[5,1-b]- and [1,2,4] Triazino [3,2-b]quinazoline Nucleosides of Fluorescence Interest . Journal of Chemistry, 2013. http://dx.doi.org/10.1155/2013/612756

M. Rashid et al., (2015). Design and synthesis of benzimidazoles containing substituted oxadiazole, thiadiazole and triazolothiadiazines as a source of new anticancer agents. Arabian Journal of Chemistry, http://dx.doi.org/10.1016/j.arabjc.2015.08.019

Mosselhi, A. Mosselhi, N., \& Laila, M. B. (2011). Nucleosides 79: Synthesis, structure, and biological, activity of new 6-arylidenamino-2-thio- and 2-benzylthiopyrimidine N-nucleosides. Nucleosides. Nucleotides and Nucleic Acids, 30, 681-695. http://dx.doi.org/10.1080/15257770.2011.597628

Mosselhi, M. A. N., \& Break, L. M. (2011). NUCLEOSIDES 7: synthesis, structure and biological activity of new 6-arylidenamino-2-thio- and 2-benzylthiopyrimidine N-Nucleosides. Nucleosides Nucleotides and Nucleic Acids, 30(9), 681-695. http://dx.doi.org/10.1080/15257770.2011.597628

Peng, L., Ashoke, S., \& Chung, K. C. ( 2008). Fluorinated Nucleosides:Synthesis and Biological Implication. J. Fluor. Chem., 129(9), 743-766. http://dx.doi.org/10.1016/j.jfluchem.2008.06.007.

Samuthirarajan, S., Mayilvasagam, K. (2014). A facile and highly chemoselective synthesis of 1,2-disubstituted benzimidazoles using hierarchical nanoporous material. Tetrahedron Letters, 55, 1971-1974. http://dx.doi.org/10.1016/j.tetlet.2014.01.140.

Sharma, A., Luxami, V., \& Paul, K. (2013). Synthesis, single crystal and antitumor activities of benzimidazole-quinazoline hybrids. Bioorg Med Chem Lett., 23(11), 3288-3294. http://dx.doi.org/10.1016/j.bmcl.2013.03.107

Violeta, R., Ruiz, A. C., \& Marı'a, J. S. (2010). New route for the synthesis of benzimidazoles by a one-pot multistep process with mono and bifunctional solid catalysts. Tetrahedron, 66, 730-735. http://dx.doi.org/10.1002/chin.201021119

Vorbruggen, H., Krolikiewicz, K., \& $\quad$ Bennua, B. (1981). $\quad$ Chem. Ber., $114, \quad 1234$. http://dx.doi.org/10.1002/cber.19811140404

Zemplen, G., Gerecs, A., \& Hadacsy, I. (1939). Ber. Dtsch. Chem. Ges., 69, 1827.

\section{Copyrights}

Copyright for this article is retained by the author(s), with first publication rights granted to the journal.

This is an open-access article distributed under the terms and conditions of the Creative Commons Attribution license (http://creativecommons.org/licenses/by/3.0/). 